\title{
PEBBLES IN THE TEACHER'S SHOES: PORTRAITS AND CHALLENGES OF RELIGIOUS MODERATION OF ISLAMIC RELIGIOUS EDUCATION TEACHERS
}

\author{
Syamsurijal \\ Balai Litbang Agama Makassar \\ Jl. A.P. Pettarani No.72 Makassar, Indonesia \\ Email: bhatijalgol@gmail.com
}

Article received March 14 ${ }^{\text {th }}, 2021$; Article revised April 25 $5^{\text {th }}, 2021$; Article approved May $8^{\text {th }}, 2021$

\begin{abstract}
The Islamic Religious Education (PAI) Teacher is one of the educators who is considered to have an important role in shaping students' religious understanding. Of course, the understanding of religion expected to emerge from these PAI teachers is a moderate one that is not extreme and does not exaggerate in expressing certain religious views. However, in some cases, it was found that PAI teachers were intolerant and even approved of radical actions in the name of religion. This qualitative research method aims to describe the portrait as well as the challenge of moderation for Islamic Religious Teachers, especially those in Madrasah Aliyah and Sekolah Menengah Umum (SMU). This research was conducted in two regions in South Sulawesi, Bulukumba and Makassar. The results showed that some Islamic education teachers still have problems in their views and attitudes of religious moderation, especially in their acceptance of diversity. Regarding nationalism, there are still several obstacles, for example, PAI teachers who prohibit flag ceremonies. But on the other hand, the religious moderation of the PAI teachers shows a lot of hope. There are still many PAI teachers who have a good religious perspective and attitude. Some PAI teachers affiliated with certain religious groups have puritanical and exclusive view. Still, in certain matters, such as the acceptance of the Republic of Indonesia, they are starting to be moderate. The right approach and intervention will be able to overcome the obstacle of intolerance among Islamic Education Teachers
\end{abstract}

Keywords: religious moderation, islamic education teacher, tolerance, nationalism

\section{INTRODUCTION}

$\mathrm{I}$ $\mathrm{n}$ the last eight years, we were surprised by the various research results showing that the school environment has also been exposed to exclusive and radical religious understandings. The Maarif Institut in his 2013 research in six urban districts in five provinces in Indonesia found symptoms of the strengthening of radicalism in schools (Fanani, 2013: 24). The same thing was stated in Syamsurijal (2017), Radicalism of Educated Youth in Makassar.

Where did this radical understanding come from? The Maarif Institute found three entrances to radicalism in schools. The three doors are extracurricular activities carried out by Rohis, school policies and teachers. It turned out that some of the teachers were affiliated with certain groups with radical views. The teachers then taught this understanding to their students in Teaching and Learning Activities (KBM) (Maarif Institute, 2017: 9).
In the PPIM study in 2016 which specifically examined the Views of Islamic Religion Teachers on Religious Tolerance, it showed that these educators were on average intolerant. It is said that $80 \%$ of them were not willing to accept that the principal and head of their region are led by non-Muslims (PPIM UIN Syarif Hidayatullah, 2016).

In 2018, PPIM once again conducted a study on the religious understanding of teachers as a whole. Among the respondents there were $19.62 \%$ Islamic Religious Education Teachers (hereinafter referred to as PAI Teachers). The results showed that around $53,06 \%$ of teachers in Indonesia were implicitly intolerant and $10.1 \%$ were very intolerant. While explicitly $50.87 \%$ of teachers have an intolerant opinion and $6.03 \%$ have a very intolerant opinion (PPIM UIN Syarif Hidayatullah, 2018: 12-18).

The entrance to radicalism in schools through teachers, especially the aforementioned PAI teachers, of course, needs to be underlined. In Law No. 20/2003 on National education and Government 
Regulation No.55/2007 on Religious and Religious Education, it is stated that Islamic education teachers in schools must form good and responsible Muslims and form good citizens in a country based on Pancasila and the 1945 Constitution. Based on this, a PAI teacher has Islamic and state responsibilities. In this case of statehood, a PAI teacher is obliged to form moderate students, that is, those who can accept and appreciate diversity, and can accept Indonesia in the form of a Unitary State based on Pancasila.

The understanding of religious moderation itself is one of the important issues in Indonesia. Religious moderation is included in the 2020-2024 RPJMN. Within the Ministry of Religion, several points have been formulated concerning the issue of religious moderation in the text of the Jakarta Charter. With the inclusion of the issue of religious moderation in various government policies and programs, religious moderation should be stronger in the school environment.

However, some challenges to religious moderation keep haunting the school environment, including the teachers. Among them is the remained strong influence of Islamism, especially among Muslim teachers and even more by PAI teachers. Even though the latter are educators who are considered to have a fairly strong religious understanding. But in fact, some of them are exposed in the extreme.

Islamism itself is an understanding that places Islam not only as a religion and a reference to values, but as an ideology that regulates all aspects of life in detail, including the state structure. This attitude often prevents its followers from accepting views that contradict their views, especially in the question of the form of the state, which according to the group must be a religious state. To this day, the view of Islamism, as referred to by Asep Bayat (2011), is still ingrained in the heads of adherents and is spread in such a way even though they are already in a democratic country.

In such a context, this paper will reveal the true portrait of the understanding of religious moderation among Islamic Education Teachers. By taking the case of PAI teachers at the Madrasah Aliyah and High School (SMU) levels, this paper will analyze the perspective and attitude of religious moderation of these educators in Bulukumba and Makassar. The two places are thought to be the places for the development of Islamist groups in South Sulawesi. Surely, this paper does not only describe the understanding of PAI teachers, but also the challenge of moderating religion itself in the teacher's environment, even though many related policies have been put forward.

\section{LITERATURE REVIEW}

Since the last few years, writings on religious moderation, especially moderation in Islam, have appeared quite many. Quraish Syihab, for example, wrote a book on moderation or wasathiyyah in Islam. By quoting some scholars, for example Ibn Jarir Atthabari, Quraish interpreted moderation which comes from the word wasatha, as the best. Quraish also quoted Al-Razi's understanding of wasathiyyah which was based on the word fair. Wasathiyyah also means balance (tawazun) and being tolerant (tasamuh) (Shihab, 2019: 7-9).

Islam, thus, sees religious moderation in three aspects. They are justice, tolerance and balance. This has also been clearly stated by the Lajnah Pentashihan Al-Qur'an Team, that in Islam there are three inherent principles: fairness, balance, and tolerance (Hanafi, 2012: 10).

Religious moderation offers a way of being religious in the midst of rampant radical movements in the name of religion today. Unfortunately, religious moderation is often misunderstood as a way of religion which seeks to take the religion easy and is inconsistent with the practices that the religion teaches.

The Ministry of Religion has issued a kind of religious moderation guide in its published book: "Religious Moderation of the Ministry of Religion" (Ministry of Religion Compilation Team, 2019). In this book, religious moderation is not viewed as an inconsistent way of religion, let alone a way of religion that compromises different theological beliefs at all. On the other hand, religious moderation is an attitude of selfconfidence and genuinely carrying out the principles of the teachings of each religion, especially regarding justice and a balanced attitude. An attitude that truly implements religious principles is accompanied by a readiness to accept and share the truth, as far as religious interpretation is concerned, as 
well as being receptive, willing to listen, open and able to cooperate with followers of different religions and ethnicities.

Washatiyah is thus a good attitude or behavior by taking a position in the middle, being balanced and not being extreme in one position (Ministry of Religion Compilation Team, 2019: 18-19). In the context of its relationship with a different ethnicity, ethnicity or religion, religious moderation is a religious practice that can accept the existence of other religions and ethnicities and is able to position these different groups fairly and proportionally.

In the Pocket Book of Questions and Answers on Religious Moderation of the Ministry of Religion, religious moderation can be seen in three ways: First, upholding human values without violating boundaries; second, respecting mutual agreement as part of the Indonesian nation, and third, respecting public order by not violating specified boundaries (Ministry of Religion Drafting Team, 2019).

One of the important factors from the first point above is tolerance (tasamuh). Someone who has moderate understanding in religion will be a tolerant person and can accept and appreciate differences. Tasamuh is one of the principles adhered to in Islamic teachings, in addition to the attit ude of al-adl (fair), tawazun (balanced) and tawasuth (moderate). Of course Islam contains a lot of teachings about this tasamuh, both contained in the Al-Qur'an, hadiths and the opinions of the Islamic scholars.

Tasamuh in Islamic teachings is interpreted as an attitude of respect for fellow human beings, whether they are of the same religion, ethnicity or language or towards those who are different. This tasamuh attitude is also reflected in behavior that is not selfish and appreciates the diversity of cultures that live and develop in society.

In a book that discusses pluralism edited by Milner and Walzer (2003), there are two keywords that have been repeated by the author to create pluralism or tolerance, that is, justice and equality. The first one requires fair attitudes and behavior towards different groups even though the different ones are minority groups in one environment. The second is equality in all aspects of life (Milner \& Walzer, 1995).

In the school environment, teachers can demonstrate fairness and equality by respecting the rights of students who differ from their own religions. The teacher treats all students equally, regardless of religion, ethnic group and ethnicity. Teachers do not discriminate against religious differences. A fair attitude can also be shown by the willingness to be led by principals of different religions, if those concerned are deemed eligible.

Andrew Cohen emphasized tolerance on the two keywords intent and noninterference. Cohen describes tolerance as: "a deliberate act by a person with the principle of refraining from interfering even though he believes he has the power to interfere" (Cohen, 2004).

Cohen's emphasis is on the attitude of the majority group not to interfere with the rights of minority groups. The attitude that emerged was deliberate, so not because of indifference to the other group. Russel Poweli and Steve Clarke clarify tolerance which emphasizes these two things by citing an example of a certain religious person (for example Catholic) allowing other religions to worship in their environment, even though he has the ability to prohibit them, because they are the majority in that place (Powell and Clarke, 2013).

In the school environment, this is manifested by the existence of a clear commitment from the teachers to give permission for students of different religions to perform their worship. Apart from that, the teachers also did not question students who show their religious symbols, as long as it did not disturb school order.

\section{RESEARCH METHOD}

This study used a qualitative method. In qualitative research, data related to the understanding of religious moderation in PAI teachers were explored and described systematically, factually and accurately (Spradley, 1997). In qualitative research, researchers become an important instrument in digging up data accurately, to the level that what Geertz calls the thick description (Geertz, 1973: 147). This thick description process was carried out by looking at the description of the informant's (Islamic Education teacher) statement as a network of signs that culminated in the deepest meaning. What was conveyed by the PAI teacher regarding religious moderation, it is only seen 
for a while as a surface description. That is what was explored continuously to find the deepest layer of meaning.

Because this research was conducted during a pandemic, there were several obstacles to explore deeper into the data because the depths of the data in this study are indeed one of the problems. However, the steps to find data as usual in qualitative research were still carried out, namely interviews and observations. Interviews were limited to strict Health Protocols and in-depth was conducted using social media (video calls, via phone and zoom).

\section{DISCUSSION}

Preference of Religious Understanding of PAI Teachers in Bulukumba and Makassar

Overall, PAI teachers in Bulukumba according to data from the Islamic Education Teachers Association (AGPAI) South Sulawesi totaled 756 people. It represents the whole level, from kindergarten to high school. Meanwhile, Islamic Education (PAI) teachers at the high school level in Bulukumba are spread across 42 schools; fourteen Madrasah Aliyah, eighteen SMU and ten SMK respectively. On average, in MA there are 7 PAI teachers, while in SMU and SMK there are 3 PAI teachers. Thus the PAI teachers in Bulukumba specifically at the high school level are nearly 200 people. The PAI teachers have various religious preferences, although on average, the teachers admit to being not active in certain religious organizations.

In general, PAI teachers who are in MA, SMU and SMK are Tarbiah scholars from Islamic Universities. Most of the PAI teachers are from the Alauddin Makassar State Islamic Institute (IAIN) (now the Alauddin Makassar State Islamic University (UIN)). There are also those from the AlGazali Bulukumba College and the Islamic College in Wajo.

Some of the PAI teachers during their time as university students joined extracampus organizations. There are those at the Islamic Student Association (HMI), the Indonesian Islamic Student Movement (PMII) and also at the Muhammadiyah Student Association (IMM). It was just that from some of the PAI teachers the writer asked, they admitted that they were members of the organization, but not activists.
One of the PAI teachers admitted that he had participated in cadres in the Indonesian Islamic Student Movement (PMII) at the IAIN Tarbiah Faculty. To this day he still feels part of the Nahdiyin. From the tendency of his religious understanding, it can be seen that he is indeed a nahdiyin. for example he still celebrates the tradition of pilgrimage to the grave, maulid and so on. In his view of diversity, this PAI teacher does not fully reflect NU's way of thinking in general.

In general, the religious understanding preferences of Islamic Education teachers in Bulukumba can be broadly categorized into:

The first category is PAI teachers with traditional religious understanding. They still practice traditional religious practices such as performing maulid, burial pilgrimages, rituals of ascending to a new house and so on. There are PAI teachers in this category who expressly claim to be NU administrators or NU congregations, there are also those who claim to be followers of the tarekat and some feel they do not belong to any organization. The second one is PAI teachers with are openly and clearly affiliated with modernist groups, such as Muhammadiyah.

The last is PAI teachers whose religious understanding tends to be salafism. But most of them do not admit or do not understand that they are part of a certain Salafist group. They only feel that they are Muslims who are trying to refine Islamic teachings so that they try to avoid religious activities that they consider not in religious teachings. Because of that, they avoided Mawlid, Isra Mi'raj and other activities that are considered to be mixed with tradition.

In the context of this religious understanding, the original salafism is a group that consistently follows the salaf ulama. In this sense, almost all Islamic groups, especially among Sunnis, consider themselves to be salafist. NU, as recognized by $\mathrm{KH}$ Hasyim Asyari, in this sense is also a salafi group, because it follows the four imams of the mazhab who are classified as salafi scholars (Asy'ari, 2020). In the current map of global religious movements, salafist has become a group of religious movements which according to Al-Ayubi tends to be dogmatic and doctrinal and always want to return to an authentic source of Islam. Apart from 
literalist-scriptualists, salafi groups also often find it difficult to accept different understandings (Ayubi, 1991).

Meanwhile, the number of PAI teachers in Makassar, which is far more than in Bulukumba district, tends to have a more diverse range of religious beliefs. The number of PAI teachers in Makassar, according to AGPAI-South Sulawesi data, is around 1229 people. The number is spread from kindergarten to senior high school. For the SMU-MA level alone, there are around 400 PAI teachers spread across several schools in Makassar.

The larger number of PAI teachers in Makassar have various religious preferences. There are those who tend to have a religious understanding of Ahlusunnah Wal-jamaah, some are emphasized again by ahlusunnah wal jamaah al-nahdiyah. PAI teachers with the preference of Ahlusunnah waljamaah alnahdiyah are those who clearly claim to be members and even administrators of NU. There are also PAI teachers who are salafi. However, in contrast to Bulukumba, which tends to be dominated by one group of salafi, PAI teachers in Makassar come from different salafi groups. Among them are Wahdah Islamiyah, salafi al-Sunnah and several other salafis. Even before the strict supervision of the jihadist salafi groups, there were also PAI teachers who were part of this group.

When HTI had not been explicitly banned by the government, some of the PAI teachers were also part or at least sympathizers of the HTI group. There are those who teach in public schools and of course also secretly spread their ideological understanding, especially about the caliphate. Recently, the issue of the PAI teacher who is sympathetic to HTI has not been heard from again. It could be that they have stopped being part of HTI because they are considered a banned organization. It is also possible that they no longer appear openly showing their tendency to be HTI-leaning.

PAI teachers in Makassar on average come from Religious Universities, especially from IAIN / UIN Alauddin Makassar. Some of them come from higher education institutions outside South Sulawesi and some even have graduated from abroad. The college backgrounds of these PAI teachers do not determine the style of their religious understanding, except those from religious colleges run by salafi groups. The style of their religious underst anding is more determined by the affiliation of their religious organization. This can be seen from several PAI teachers who were interviewed, although they came from the same university, for example from UIN Alauddin, but the tendency of their religious understanding to be different after being active in certain religious organizations.

When HTI had not been explicitly banned by the government, some of the PAI teachers were also part or at least sympathizers of the HTI group. There are those who teach in public schools and of course also secretly spread their ideological understanding, especially about the caliphate. Recently, the issue of the PAI teacher who is sympathetic to HTI has not been heard from again. It could be that they have stopped being part of HTI because they are considered a banned organization. It is also possible that they no longer appear openly showing their tendency to be HTI-leaning.

PAI teachers in Makassar on average come from Religious Universities, especially from IAIN / UIN Alauddin Makassar. Some of them come from higher education institutions outside South Sulawesi and some even have graduated from abroad. The college backgrounds of these PAI teachers do not determine the style of their religious understanding, except those from religious colleges run by salafi groups. The style of their religious understanding is more determined by the affiliation of their religious organization. This can be seen from several PAI teachers who were interviewed, although they came from the same university, for example from UIN Alauddin, but the tendency of their religious understanding to be different after being active in certain religious organizations.

Several PAI teachers in Makassar claim to have no affiliation with any religious organization or sect. They only claim to be ordinary PAI teachers whose activities are teaching every day. It's just that they admit that they have learned a lot about religious issues from online media. Watch lectures on YouTube or listen to scholars' reviews spread on various social media.

The active participation of several PAI teachers in accessing religious issues from online media has inevitably influenced their religious perspective. One of the PAI teachers, mention her name Syamsiah, 
admitted that previously she still practiced many things that had no religious guidance. For example, Syamsiah stated, in the past, she still often performed religious events that were inherited from her ancestors, but after hearing the sermons of salafi scholars, she began to abandon some of her habits.

\section{Potraits and Challenges of Religious Moderation among PAI Teachers}

The term religious moderation among PAI teachers is not yet popular. One PAI teacher named Rahmi (a pseudonym) in Bulukumba, confuses the term religious moderation with religious modernism. Shee stated that religious moderation is actually using rational thought in religion by leaving all religious methods that still reek of khurafat, superstition and heresy. In essence, according to Rahmi, religious moderation is a more advanced religion by leaving all religious methods that still mixed with traditional things.

Another PAI teacher admitted that he frankly did not understand the term religious moderation and had only just heard of it. But once it is explained that religious moderation is a way of religion that is not extreme or radical but takes the principle of the middle way, tolerance and respect for diversity, they state that this has become part of the material taught to students.

Not only in Bulukumba, even in Makassar with faster access to information, it turns out that there are still many PAI teachers who do not know exactly what religious moderation is. Of course, when described in more detail, they can immediately tell what is meant by religious moderation.

Religious moderation has indeed only been popularized in the last three years by several intellectuals. Books related to the term also appeared. One of them was written by Quraisy Syihab: "Wasathiyyah, Islamic Insights on Religious Moderation (Shihab, 2019). Another book is published by the Ministry of Religion through the Research and Development and Training Agency, namely a book entitled Religious Moderation (2019). If traced back, several years ago, Wasathiyyah Islam itself was once echoed by both NU and Muhammadiyah circles, but the term was faint, after NU itself raised the term Islam Nusantara which eventually sparked public attention.
Referring to the pocket book on Religious Moderation compiled by the Writing Team of the Ministry of Religion, religious moderation is emphasized on three things, namely: First, upholding human values, including in terms of being tolerant and avoiding discriminatory attit udes towards those who are different. Second, accepting a common consensus as a nation and thirdly not disturbing public order (Drafting Team of the Ministry of Religion, 2019).

In this paper, the portrait of religious moderation of Islamic Education teachers is seen in three ways. These three things are still part of the three aspects mentioned above. First, attit ude and the view of PAI teachers on the relationship between religion and the state, that is, how they view the current form and basis of the Indonesian state, as well as their views on the desire of certain groups to replace it. Second, their views on diversity or tolerant attitudes, and third, the views of PAI teachers on the culture and religious practices of the Indonesian people which are mostly based on amalgamation of religious teachings and traditions.

Of the three things, the first point shows that the portrait of religious moderation in Islamic Education is quite promising. The majority of PAI teachers accepts the current form of the Indonesian state which is not a religious state, but instead makes religion a source of value and inspiration in the state.

In the context of the form of the state, the basis of the state and the rules of the state that have become a collective agreement, the average Islamic Education teacher gives the opinion that currently there is nothing that needs to be questioned. What has been agreed upon by the founders of this nation has proven to be the most suitable for the Indonesian state, which is a pluralistic country.

Some PAI teachers with various backgrounds (NU, Muhammadiyah, Salafi or those without religious organization affiliation) seem congruent in that they do not question the current state form. They tend to say that changing the current state form in Indonesia will only create chaos. This is as said by one of the PAI teachers at a MAN in Makassar:

The current form of our country is the most appropriate, namely the Unitary State of the Republic 
of Indonesia which is based on Pancasila. I often tell students that the desire to change this country into a caliphate is impossible and unrealistic because our nation consists of various religions. If we impose the form of a caliphate state, what about other religions? Of course they are difficult to accept. As a result, disunity can occur.

The same thing was conveyed by one of the PAI teachers at a high school in Makassar. According to him:

A PAI teacher must be clear in the matter of nationality, and I can guarantee that PAI teachers in our schools do not have any more problems regarding the shape of the state, the basis of the state and our current constitution. This is an important basis for building unity. If you look for another form of state that is sectarian, it is very worrying that it will cause disunity between various ethnic groups and religions in Indonesia.

Meanwhile, a PAI teacher with a salafi background in Bulukumba also criticized the desire of a group of people who wanted to change the form of the state or jihad abroad, for example to Syria. The female PAI teacher said this:

"I always emphasize to my students, to be careful with teachings inviting jihad that they might get outside. Jihad today for a student is not going to war, let alone carrying out acts of terrorism. Jihad for students is to study seriously, to become a successful Muslim who can boast of Muslims. To enforce Islamic law, it is not necessary to go to war to establish an Islamic state, it is enough to make this society a society with sharia. For that, it starts with each person to implement Islamic law in daily life correctly and consistently. "

The views and attitudes of PAI teachers regarding the relationship between Islam and the state were increasingly being tested in several MA schools, when materials on khilafah and jihad were included in the 13 (K-13) curriculum. This material is included in the subject of fiqh, in the early chapters, although recently this material has moved to the History of Islamic Civilization. This was told by a PAI teacher at a MAN in Bulukumba. According to the PAI teacher who is also a woman, the material actually tests the PAI teacher's bias towards the form of the Republic of Indonesia with the current Pancasila foundation. For her, it is precisely through these materials that she can explain how to put the caliphate and jihad into the various differences of opinion of the scholars. As well as how to put it this time. Through material on khilafah, he can explain that khilafah is only one system among many systems. Which question is the most Islamic is one which can be applied based on Islamic values. The current form of the Indonesian state can also be very Islamic, because the values that guide it, such as Pancasila, which also a very Islamic values and a legacy of the ulama.

However, as acknowledged by several PAI teachers in MA, the material about caliphate and jihad that has been included in the fiqh curriculum can indeed be a doubleedged knife. This material can be used not only to erode the love of the country of the students, it can also be used as propaganda for jihad, which is always synonymous with war. But on the other hand, it can also be used as material to instill love for the country and jihad in terms of that does not forever mean wars. Several PAI teachers who were met and had taught this material, on average said convincingly, that through this material they could actually explain that currently the form of the Indonesian state (NKRI which is based on Pancasila) is the most ideal.

Even though the majority of PAI teachers no longer have an issue with the shape of the state and the basis of the state at this time, there are still differences in the views of PAI teachers in realizing nationalism in everyday life (daily nationalism). Does showing nationalism symbolically in everyday life have to be done or is it a form of acceptance and love for the country that is manifested in the form of true teaching as an effort to educate the nation? Is it still important to have nationalism that is symbolic and looks simple or in the terms of Michael Billig (1995: 5-7), Banal Nationalism or is it no longer necessary?

Banal nationalism is usually manifested in the form of ceremonies to commemorate certain days, for example the 17 August ceremony, the hero day ceremony, even in offices and schools the flag ceremony is held every Monday or the 17th of every month. What Billig calls banal nationalism includes flying a flag in every yard of the house or office, holding a carnival on independence anniversary, singing the Indonesia Raya song as holding an official event, and memorizing Pancasila and the 1945 Constitution and others. 
In this current situation, there is no upheaval to fight against the invaders, then this banal nationalism becomes an alternative to show the existence of one country. Therefore, no matter how simple the model of banal nationalism is, for Billig (1995) its existence is still important. Therefore, government agencies or schools that are diligent in holding flag ceremonies are still needed.

Regarding the flag ceremony, saluting the flag or singing Indonesia Raya songs as a simple form of commitment to the Republic of Indonesia, it is not a problem for PAI teachers who come from NU, Muhammadiyah or those who feel they have no religious organization affiliation. But this is not the case with some PAI teachers who have salafi backgrounds. Flag ceremonies and flag saluting can be considered inconsistent with religious teachings.

The differences in seeing the form of nationalism in everyday life is what often occurs among Islamic Education teachers. In particular, PAI teachers who are salafioriented, many have questioned the ceremony or even saluted the flag. This is our question: Can this view be considered an exaggerated way of religion? If it is considered excessive, it means that they no longer apply moderate principles in religion.

A PAI teacher said that he was currently still participating in the flag ceremony and following the whole series of ceremonies, because he is a state servant who must obey the ulil amri. But that doesn't mean agreeing with the ceremony and saluting the flag. If it was not done, it would be much better and this form of love for the country would be manifested in another form.

The thing that needs to be underlined from this statement is that a person, including in this case a PAI teacher, who has the view that flag ceremony and saluting the flag is "not allowed" does not mean that he does not accept this form of the Indonesian state. It's just that this form of acceptance cannot be fully implemented if it is considered contrary to religious teachings. In other words, the person concerned experiences the problem of nationalism if he wants to apply it in everyday life. They cannot run it straightforwardly if they consider it to be contrary to their religious understanding.

However, most of those who have this kind of view, in the end still choose to participate in the ceremony and honor the flag, with the assumption that obedience to ulil amri must come first. But basically this views have not changed. Even among the teachers affiliated with the salafi group, there were those who strictly did not want to participate. Others chose to leave teachers with the status of a State Civil Apparatus (ASN) rather than having to follow the rules of an ASN.

As there are various salafi groups, the salafi understandings that have penetrated among teachers are also different. Referring to Thomas Hegghammer's view, at least salafi can be categorized into three groups (Hegghammer, 2009: 74-77). First. purity salafi, that is, salafi who maintain their movements only in the aspects of worship and education and avoid political movements. The two haraqi salafi (politico-salafi), namely salafi who are not only active in education and preaching, are also active in responding to political problems in the country and political developments abroad, especially in Islamic countries. They are also active in political movements. Third, the salafi jihadi is that is at extreme. In addition to closed-scriptualism, and labeling deviant, bid'ah and kafir against sects that are not of the same opinion, it also permits acts of violence and terror.

It seems that the current developing PAI teachers are salafi in two categories, namely purity salafi and salafi haraqi. They do not want violence but understand the text behind closed doors and do not accept outside views, including regarding the law of saluting the flag and participating in ceremonies. It's just that the salafi purity even though they believe that the flag ceremony is haram and respect the flag is not allowed, but because they follow Ulil Amri, they eventually join the flag ceremony. Those who remain adamant about not participating in the ceremony are those who belong to the salafi haraqi.

In the context of religious moderation, the view of the teacher who rejects the flag ceremony on the basis of religion can be considered an exaggerated way of being religious. Although there are scholars who think so, especially from salafi-wahabi, but there are also permissible views. Indonesian ulama, as exemplified by KH Maimun Zubair, are even eager to pay homage to the red and white flag. Kiai Zubair even stood up when the song Indonesia Raya was sung. Guru Tua or Habib Idrus bin Salim Al-Jufri, founder of the 
Al-Khaerat Islamic Boarding School, makes poetry about the symbol of red and white as pride. In one of his verses, it is mentioned that Kullu Ummatin Laha ramzu izzin, wa ramzu izzina al-hamraa wa al-baydhoo '(All nations have a symbol of glory and our symbol of glory is red and white (flag)). For scholars like Old Guru, respecting the flag is not worship, but merely shows that we respect the symbol of glory as a nation. Salafi-affiliated PAI teachers did not consider this view at all. They took the opinions of the ulama they respected to the extreme.

Meanwhile, in the matter of PAI teachers' acceptance of diversity and tolerance, it appears that there are still some problems. For example, there are cases where PAI teachers still find it difficult to accept other different groups. One of them is the case of a PAI teacher prohibiting Muslim students from associating with non-Muslim students. This happened in a high school in Bulukumba. This case can indeed be resolved by the local Ministry of Religion. The teacher concerned, after being reprimanded, also began to change a little in seeing different groups, but what is certain is that this intolerance is still common among PAI teachers.

PAI teachers on their view of diversity can be divided into several categories:

First, PAI teachers who can accept diversity, including in this case accept the religious practices or traditions of other Islamic groups without any conditions. They can also accept that other religions or other groups have the same rights as citizens and should not be prevented from being able to use these rights, for example the right to worship and build houses of worship.

If you look at the backgrounds of PAI teachers who can accept this unconditional diversity, they are quite diverse. Some are affiliated with religious organizations such as NU or Muhammadiyah, but there are those who claim not to have any religious organizations. While those who were currently studying on campus were active in extra and intra-campus organizations, it seemed that their organization had an influence. This is reflected in several PAI teachers who admitted that when students became activists of the Indonesian Islamic Student Movement (PMII) and the Indonesian Islamic Student Association (HMI). It's just that those who just join extra-campus organizations, but are not active or become activists, it seems that their views are not much influenced by the organization.

Meanwhile those affiliated with religious organizations such as $\mathrm{NU}$ and Muhammadiyah seem to have quite influenced the PAI teacher's views. But specifically for this first category, namely those who accept unconditional diversity, a difference can be seen between the PAI NU teachers in Makassar and Bulukumba. PAI teachers with NU backgrounds in the city of Makassar generally understand diversity as sunatullah and must be accepted without any conditions. Meanwhile, PAI teachers with NU backgrounds in Bulukumba can also accept diversity, but with various signs posted as boundaries. There is an impression that the paradigm in understanding the diversity between NUs that exist at the central or regional levels is not exactly the same as what is happening in the regions.

Another thing that influences PAI teachers in accepting diversity to the level of active tolerance is the current environment and place of religious learning. PAI teachers who are in a diverse environment, both socially and in their school environment, have a more active understanding and practice of tolerance. They are not awkward hanging out with people of different religions, they visit and congratulate each other at the time of certain religious events. This could also explain why Islamic Education teachers in SMA have tolerant thoughts and attitudes. This is because the PAI teachers live in a fairly diverse school environment, they are used to meet people of different religions or ethnicities. Paul Suparno (2019) in his writing "Helping Teachers to be More Tolerant, also states that a homogeneous teacher environment does not support the emergence of tolerance, on the other hand, heterogeneous conditions can encourage the emergence of tolerant attitudes.

However, the diverse school environment cannot absolutely support the viewpoint of tolerance of PAI teachers, if the social environment outside the school is only the same group. For example, they only have homogeneous organizations and arisan groups. Including in this case they must be supported by a moderate source of religious knowledge, they are active in recitation in inclusive groups and the scholars where they study are moderate scholars. 
Second, PAI teachers who can accept diversity, but have certain conditions and restrictions. This second category is the common view of Islamic Education teachers. Tolerance or acceptance of diversity has limits. Between these boundaries are theological boundaries as the first boundary. As long as this tolerance is deemed not to interfere with theology (what is meant by mainstream group theology), then this tolerance can be carried out. That is why, most of the PAI teachers who were met, could not accept the existence of the Shia and Ahmadiyah groups. Although both of them are of the same religion, they are considered to be disturbing theological issues that have been established in the majority of Muslims in Indonesia. In the case of Shia and Ahmadiyah, these PAI teachers did not want them to exist, but also did not want acts of violence. Therefore, the state is expected to take action in dissolving or not legalize its existence in Indonesia.

One of the PAI teachers at a high school in Bulukumba stated this:

\section{"I certainly do not agree with the existence of Shia and Ahmadiyah, but I also do not agree if they are persecuted or experience violence from society. For this reason, the government needs to step in, for example limiting the space for this group even if necessary to dissolve it".}

Second, the terms of tolerance must not interfere with public order. In the view of Robert W. Hefner, the public interest is actually the interest of the majority group. The existence of other groups, including their freedom to express their religions and beliefs, must not interfere with the interests of the majority in their respective regions (Hefner, 2020: 5-7).

Third, they also tend to see this tolerant attitude as an attitude of other religions that can dissolve into various Muslim activities. But on the contrary they limit if Muslims want to immerse themselves in nonMuslim religious activities. Some PAI teachers, for example, told happily if any of their non-Muslim students helped prepare for the maulid, so the maulid committee and participated in the maulid event. On the other hand, if asked, "what if Muslim students also help with religious events for non-Muslim students?" The answer: "If this is the case we must be careful, because in the teachings of Islam there are limitations. We are also afraid that what we are doing violates the boundaries of the faith."

This tolerance can be called conditional tolerance, namely tolerance which when they want to help or associate with people of other religions, they are fulfilled with various conditions, on the contrary it is happy if followers of other religions want to mingle in their religious activities. This kind of tolerance regime still leaves power in it. In the view of the famous Stephen L. Carter, this condition implies that: the language of tolerance is the language of power. In other words, the expression "I tolerate you," is always accompanied by certain conditions, namely, those who are tolerated must be dissolved into the majority group and if necessary by removing their identity (L. Carter, 201: 75).

In Hefner's latest findings on pluralism in Indonesia, he mentions a kind of covenantal pluralism (agreement pluralism). Quoting Chris Seiple, Hefner states that this covenant pluralism goes beyond simply coexistence in diversity without engaging with one another. In this covenant pluralism there is a kind of collective (sometimes unwritten) promise to engage, respect and protect one another. This respect is without having to assume that their beliefs or religions are equivalent to other beliefs (Hefner, 2020: 5).

In covenant pluralism too, Hefner still quotes Seiple, will not destroy or ratify theological truth. Nor can it embrace minority groups to act as equals with the majority. The minority is assimilated and integrated into the majority group. From this it is hoped that the common good or stability in life will emerge (Hefner, 2020: 1-2).

According to Hefner, the pluralism of the covenant in Indonesia is contained in constitutional law. Others also occur in society. In society there is also a kind of unwritten agreement, which seems to be an agreement on how tolerance is applied. In short, it can be said that the covenant pluralism referred to by Hefner, imposes limits on tolerance or pluralism itself. This limitation is necessary in order not to interfere with religious values (the religion of the majority) and public order. In this kind of pluralism, limiting the religious rights of individuals or minority groups is possible in order to safeguard the sovereignty of the majority group's theology. Ahmadiyah and Shia can be 
limited, if they are considered to be disturbing and tarnishing the theology of the mainstream Islamic groups.

The ways in which society, including Islamic Education teachers construct tolerance with various limitations, as stated above, may be a reflection of what Hefner calls covenantal pluralism. In fact, the community, including in this case the PAI teacher, only builds a kind of unwritten agreement regarding tolerance, based on an agreement that has been formulated in our constitutional law. There is also tolerance in question, it is prohibited to make religious truth seem relative and prioritize protecting the interests of the majority over the freedom of religion of all religious groups.

Third, PAI teachers who have their own views about accepting the diversity and tolerance that is typical of salafis. For this third category, the PAI teachers in question are indeed affiliated with or at least active in the recitations held by the salafi groups. What is the viewpoint of this salafi-affiliated PAI teacher? Similar to the second category above, where the construction of their appreciation of diversity has certain conditions. But their conditions are more emphasized on not being in conflict with the Islamic faith or teachings. Often also mentioned, the way they respect other religions or value diversity is always based and based religious teachings. It should be noted, that according to Islamic teachings, the meaning is, according to the teachings in Islam that they understand.

One of the PAI teachers at a high school, stated this:

\begin{abstract}
"As long as this award does not interfere with Islamic faith and teachings, it is okay for us to respect other religions. Which is not allowed, for example, to wish other religions a happy holiday. This should not be done because it tends to be related to faith. Likewise, we are not allowed to enter houses of worship of other religions or provide assistance to other religions, because that is why we tend to agree with their teachings. "
\end{abstract}

Regarding not being allowed to say happy holidays to other religions because it disturbs the faith, of course according to the views of the group itself. This is because there are some scholars who actually allow them to say happy holidays to followers of other religions. For example, Quraish Shihab and the scholars of al-Azhar.
The perspective of this PAI teacher from the salafi circle has its own principles of tolerance. It's not even just a matter of tolerance, this also applies to other things. Salafis today, do not reject progress, especially in matters related to the world, but they develop their own concepts about progress, even including the issue of women's empowerment. They do not accept concepts such as tolerance, feminism, modernism from the West because they are considered not based on religious teachings. Based on that, they reconstruct themselves what it means to respect diversity, the movement for empowerment, progress and so on.

In the findings of Saba Mahmood's research on group movements of this kind (salafi and Muslim Brotherhood) in Egypt, it is stated that this group movement builds its own constructs regarding styles of dress and speech, standards regarding what is considered appropriate entertainment for adults and children. patterns of financial and household management, provision of care for the poor, a term used for public debate (democracy) and also regarding ways to relate to other religions and accept diversity (Mahmood, 2011).

The substance of the salafi concept and movement is against all Western concepts, including in this case: "tolerance" which is considered secular. Religion, according to them, has been marginalized in the daily life of mankind. Therefore, the concepts of the salafi group emphasize Muslims not only (although that is also one of them) to carry out religious and religious duties appropriately, but also to regulate their daily behavior in accordance with the principles of Islamic piety and Islamic morals.

Thus, when salafis, as illustrated by some PAI teachers have their own concept of respecting diversity and tolerance, it is not something incidental. This group does have and has reconstructed its own concepts of tolerance. They accept diversity, respect other religions, but with strict boundaries. For example, they do not agree to say happy holidays to other religions, do not agree to provide assistance to other people's houses of worship, do not want to come and hang out closely with followers of other religions and so on. In fact, they still use the term against nonMuslims as infidels.

Their tolerance is to allow other religions or other groups to practice worship, 
to be able to interact in socio-economic matters (such as trade), but all remain within the framework of Islamic-based arrangements they understand. This kind of tolerance tends to accept people who are not of the same faith, but are placed as second-class citizens.

Of course, the emergence of salafistyle concepts and views of tolerance among Islamic Education teachers influenced the pattern of their relationships at school with people of other religions. If previously, giving each other congratulations on holidays and also visiting each other's events of friends of different religions were common, then now it is starting to be questioned. Something that was previously commonplace is now starting to be questioned and finally, people's relations amidst diversity begin to seem awkward.

As long as certain groups can accept diversity, basically they can live in this multicultural Indonesian society. However, there is one weakness with the salafi construction of tolerance as well as with various other concepts in this modern society, namely the inability or unwillingness to have a dialogue with other views. There is a fundamental way of thinking in their midst, that what they understand is the most authoritative and in accordance with the salafus salih view. Their views are also considered to be fully based on the Qur'an and the Sunnah of the Prophet SAW, so that outside these views are not considered the principles of Islamic piety.

With this kind of attitude, PAI teachers who are affiliated with salafis, it is difficult to accept the possibility of truth in other views, especially from people of different religions. Referring to Walzer, this kind of tolerance can still accept people from other groups or religions, but in fact other groups or religions are considered to have no meaning (Walzer, 1997: 47).

This is reflected in the expressions of several PAI teachers who claim to be affiliated with salafis. According to them, "religion teaches respect and acceptance of other religions that are different, but only accepting life among us. The ways of life or traditions that exist in them, although they may sound good, cannot be examples and should not be followed. Muslims are prohibited from tasyabbuh (imitating other religions). "

The next problem is how PAI teachers accept or accommodate the culture and traditions that develop in society, including in this case religious traditions such as maulid, isra mikraj and also welcoming Ashura day?

In general, PAI teachers do not have a problem with this. PAI teachers with various backgrounds, including those with affiliations of various religious organizations and also those without religious affiliations, consider that the culture that lives in society must be respected. Culture or traditions such as salvation, both salvation in the life cycle of humans, as well as salvation for entering a new house, salvation related to agriculture, as long as it does not damage faith, then it is not a problem. Including, the PAI teachers can accept religious rituals or ceremonies that are full of culture in it, for example the celebration of the Prophet's birthday, isra mikraj, mappeca sure (ashura celebration) and other celebrations. Not only accepting, they even claimed to be involved in it. This applies to Islamic education teachers in Bulukumba as well as Islamic education teachers in Makassar.

Especially PAI teachers who are affiliated with NU, they seem to be more appreciative of the culture and traditions that develop in society. They are also uniform in this regard, both in Bulukumba and Makassar. One of the PAI teachers from a MAN in Bulukumba, excitedly stated:

\footnotetext{
"What is important in teaching students about religious moderation today is how to accommodate and appreciate the traditions and culture that develop in society. Like in our area, the average community is thick with cultural practices, especially those found in Tanah Toa Kajang. Therefore, we as PAI teachers try to give students an understanding that their cultural practices need to be respected because most of them contain good values".
}

In line with the statement made by a MAN teacher in Bulukumba, Irwanto, a PAI teacher at a MAN Makassar who also has a NU background stated:

\begin{abstract}
"Regarding hereditary culture, such as salvation, porridge "pitunrupa" on the day of Ashura, this is fine, as long as it is not considered an obligation that must be carried out. The implementation of salvation is a form of gratitude after we have received the grace and sustenance from Allah SWT, moreover implicitly there is also alms (various foods) in it. It is also Islamic advice and teachings for various if you have property and food".
\end{abstract}

PAI teachers, both those who live in Bulukumba and those who teach in Makassar, 
see tradition, culture and even art as a means to incorporate Islamic values. "Culture and arts can become media for preaching, so they don't need to be removed." That was the view of a PAI teacher from a MAN in Makassar. PAI teachers with this view want to bridge the religious teachings and local traditions together to stay alive and complement each other. They are in this position to act, as Geertz term, "The main connecting link" (Geertz, 1960)

Although the views of PAI teachers are almost uniform about accepting the culture that is developing in society, it turns out that there are also those who see it differently. Well, nothing is uniform under this sky. This time also came from the viewpoint of Salafiaffiliated PAI teachers. For them, there are many customs and traditions of society that have to be seen carefully and cautiously. He said that the culture that developed in the community contained many elements of idolatry and many of which were just wastefulness.

One of the PAI teachers at a high school in Bulukumba, I just call her name, Mrs. Hawaniah stated the following:

\begin{abstract}
"I personally do not agree with some of the cultures that developed in society, because it is actually the custom of our pre-Islamic ancestors. Even the maulid celebrations that mix with the traditions of the ancestors, I also disagree. For example, like the maulid held in several places such as Jeneponto and Takalar, a lot of it has been mixed with local traditions. Commemorating the maulid should be sufficient by observing and doing dhikr".
\end{abstract}

Another teacher, still a PAI teacher who frequently participates in salafi recitation in Bulukumba, stated:

\begin{abstract}
"Islam modernization (moderation is called modernization) should be none other than teaching society so that the way of religion in everyday life is more rational. They must be prevented from practicing religious teachings that mix with their ancestral traditions which are still conservative and seem to contain elements of animism and dynamism in them".
\end{abstract}

In matters of art, PAI teachers affiliated with salafis also disagree. He considered music and art lessons inconsistent with the teachings of the Prophet Muhammad. Because of that, according to the confession of a PAI teacher at a public school in Bulukumba, himself as a PAI teacher, tries to give understanding to art teachers, if there are students who do not want to be involved in art practices which are usually in the form of dances, singing and using certain music is not mandatory.

Of course the students referred to by this PAI teacher are those who have also been influenced by their views on music and art. In the name of religious belief, they asked for some kind of exemption from other teachers of the students concerned. A student or teacher does have the rights to express his religious beliefs, including for example to disagree with music and singing. It's just a problem at school, because arts subjects already have their own curriculum and material flow. When there are students who do not want to follow the flow of the curriculum, the learning targets are not actually fulfilled. This is what art teachers complain about.

The problem seen here is that there is a desire from certain PAI teachers to be tolerated in terms of what they believe, but on the other hand they cannot understand the position of other teachers. They also do not want to open up the possibility that there might be other opinions from scholars regarding musical and singing abilities. Persistence in one's own opinion or the opinion of one's group, regardless of the context in which to apply that view, may also be an exaggeration in religion. Such a way of religion, can no longer be said to be moderate.

Of the several challenges of religious moderation among PAI teachers, the most striking is the influence of certain religious beliefs on these educators. These ideas originate from the salafi recitations they participate in or also because of their affiliation with Islamist groups.

The challenge of moderation in religion in the form of infiltration of exclusive understandings is what our common homework is. Not only for PAI teachers, but this problem also penetrates the school environment in general. Teachers are affected, students are also exposed, and even schools are the basis for disseminating their teachings.

As long as the religious views and attitudes of PAI teachers who are influenced by salafism do not cause discriminatory action against different groups, then this view is still possible for dialogue with other views. They should be encouraged to listen to the opinions of other ulama, for example ulama from NU and Muhammadiyah. They are encouraged to open themselves to dialogue with knowledge 
from other religions and from other civilizations. One of the ways is by providing space for moderate religious groups to enter schools or mosques around the school to provide recitation. As long as this can be done, it is possible that the PAI teachers from this salafi can move to a more moderate point.

\section{CLOSING}

The portrait of religious understanding and moderation of Islamic Education teachers when observed from three aspects, each of which has its own challenges. First, acceptance of the national consensus, on average, there is no longer a problem. They accept the form of the Unitary State, Pancasila as the basis of the state and the 1945 Constitution as the supreme constitution in the state. But in terms of implementing nationalism commitments, such as flag ceremonies and singing the Indonesian Raya song, some Salafi-affiliated PAI teachers do not want to be involved or if involved, they are forced to join.

Second, related to the acceptance of local culture and traditions that developed in the community, PAI teachers who were active in salafi recitations seemed less accommodating. Some cultural practices are considered as relics of their different ancestors of animism and dynamism. Religious practices that are amalgamated with local culture cannot be accommodated. It is considered to contain a lot of heresy and khurafat. In short, the PAI teachers who are affiliated with salafis have not been moderate towards the culture that develops in society.

On the other hand, other PAI teachers, especially those affiliated with NU, on average did not question the traditions and culture that developed in society. If it is considered that there are elements of exclusion, then, that is what needs to be changed without having to get rid of the culture and traditions that are commonly practiced in society. For PAI teachers in this group, culture and arts can actually support the propagation and propagation of Islam.

As for acceptance of diversity or an attitude of tolerance, Islamic Education teachers in the two places studied, seemed to have different points of view. There are at least three categories of PAI teacher tolerance perspective. First, accept diversity without any conditions. They practice religious moderation well which implies an active tolerant way of life. This kind of viewpoint is supported by a multi-ethnic and multi-religious school environment, societies and everyday environments that are accustomed to diversity, moderate religious organization affiliations, the references are mostly moderate writings, and the ulama who become their references are moderate scholars.

Second, PAI teachers who accept diversity with certain conditions. Quite a few PAI teachers are in this position. The limitations in accepting such diversity are firstly based on theological reasons or religious teachings. It's just that what is meant by religious teachings is in accordance with the perspective of the group. Usually, those who always use religious reasons to limit their tolerance are mostly PAI teachers who are affiliated with salafi.

Third, there are PAI teachers who are intolerant by positioning students or of different religions as a group that cannot be accompanied in meetings and cannot be an ally because they are considered kafir or idolaters. This attitude is not only aimed at different religions, but for those of the same religion but who are still considered to be heretical and idolatrous and should not be considered as close friends. PAI teachers who have this attitude are heavily influenced by the recitations that seem exclusive so far. Most of these recitations are driven by salafi groups.

\section{ACKNOWLEDGEMENTS}

Gratitude is conveyed to all PAI teachers at Madrasah Aliyah and high schools in Bulukumba and Makassar. Likewise thanks to the Principals of the School who willing to provide schools as the research site. They have all taken the time to accompany the writer in the discussion and provide valuable information. May Allah SWT repay all the services of the people involved in helping the research process until it is formed into this paper.

\section{REFERENCES}

Asy'ari, KH Hasyim. 2020. Mahakarya Hadratus Syaikh Hasyim Asy'ari. Jombang: Pustaka Tebu Ireng.

al-Ayubi, Nazih. 1991. Political Islam:

Religion and Politics in the Arab World. London and New York: Routledge.

Bayat, Asep. 2011. Pos Islamisme. Yogyakarta: LKiS. 
Cohen, Andrew Jason. 2004. "What Toleration Is." Ethics 115(1):68-95.

Fanani, Ahmad Fuad. 2013. "Fenomena Radikalisme Di Kalangan Kaum Muda." Jurnal Maarif VIII(01).

Geertz, Clifford. 1960. "The Javanese Kijaji: The Changing Role of a Cultural Broker"." Comparative Studies in Society and History 2(2). 1973. The Interpretation of Culture. New York: Basic Books Inc.

Hanafi, Muchlis. 2012. Moderasi Islam. Jakarta: Lajnah Pentashihan Mushab Al-Qur'an.

Hefner, Robert. W. 2020. "Islam and Covenantal Pluralism in Indonesia: A Critical Juncture Analysis."." The Review of Faith \& International Affairs 18(02):1-17.

Hegghammer, Thomas. 2009. "Jihadis -Salafis or Revolutionaries?" in Global Salafism: Islam's New Religion Movement. London: Hurst \& Co Publisher.

L.Carter, Stephen. 2011. The Violence of Peace: America's Wars in the Age of Obama. New York: Beast Books.

Maarif Institute, Laporan Penelitian. 2017. Penguatan Kebijakan Ekstrakurikuler Dalam Meredam Radikalisme Di Sekolah'. Jakarta.

Mahmood, Saba. 2011. Politics of Piety: The Islamic Revival and the Feminist Subject. New Jersey: Princeton University Press.

Michael Billig. 1995. Banal Nationalism. London: Sage.
Milner, David \&Michael Walzer. 1995. Pluralism,_Justice, and Equality Oxford (1996).Pdf. Great Clarendon Street: Oxford University Press.

Powell, Russell, and Steve Clarke. 2013. Religion, Tolerance and Intolerance: Views from Across the Disciplines The New Religious Violence and the New Atheism. London: Oxford University Press.

PPIM UIN Syarif Hidayatullah, Laporan Penelitian. 2016. Pemahaman Toleransi Guru Agama. Ciputat.

PPIM UIN Syarif Hidayatullah, Laporan Penelitian. 2018. Pelitia Yang Meredup: Potret Keberagamaan Guru Di Indonesia. Ciputat.

Shihab, M. Quraisyh. 2019. Wasathiyah; Wawasan Islam Tentang Moderasi Beragama. Tangerang: Lentera Hati.

Spradley, James P. 1997. Metode Etnografi. Yogyakarta: Tiara Wacana.

Suparno, Paul. 2019. "Membantu Guru Untuk Lebih Toleran." in Post-Truth dan (Anti) Pluralisme. Jakarta: Kompas.

Syamsurijal. 2017. "Radikalisme Kaum Muda Islam Terdidik Di Makassar." Al-Qalam 23(2). doi: 10.31969/alq.v23i2.434.

Tim Penyusun, Kementerian Agama. 2019a. Buku Saku Tanya Jawab Moderasi Beragama. Jakarta: Balitbang \& Diklat Kementerian Agama.

Tim Penyusun, Kementerian Agama. 2019b. Moderasi Beragama. Jakarta: Balitbang \& Diklat Kementerian Agama.

Walzer, Michael. 1997. On Toleration. London: Yale University Press. 
